\title{
Communication
}

\section{Ultra-Fine Control of Silica Shell Thickness on Silver Nanoparticle-Assembled Structures}

\author{
Eunil Hahm ${ }^{1,+}$, Ahla Jo ${ }^{1,{ }^{\dagger}}$, Eun Ji Kang ${ }^{1}$, Sungje Bock ${ }^{1}$, Xuan-Hung Pham ${ }^{1}{ }^{(\mathbb{C}}$, Hyejin Chang ${ }^{2, *}{ }^{\mathbb{D}}$ and \\ Bong-Hyun Jun $1, *$ (1)
}

1 Department of Bioscience and Biotechnology, Konkuk University, Seoul 05029, Korea; greenice@konkuk.ac.kr (E.H.); iamara0421@konkuk.ac.kr (A.J.); ejkang@konkuk.ac.kr (E.J.K.); bsj4126@konkuk.ac.kr (S.B.); phamricky@konkuk.ac.kr (X.-H.P.)

2 Division of Science Education, Kangwon National University, Chuncheon 24341, Korea

* Correspondence: hjchang@kangwon.ac.kr (H.C.); bjun@konkuk.ac.kr (B.-H.J.); Tel.: +82-2-450-0521 (B.-H.J.)

+ E.H. and A.J. contributed equally to this work.

check for updates

Citation: Hahm, E.; Jo, A.; Kang, E.J.; Bock, S.; Pham, X.-H.; Chang, H.; Jun, B.-H. Ultra-Fine Control of Silica Shell Thickness on Silver NanoparticleAssembled Structures. Int. J. Mol. Sci. 2021, 22, 11983. https://doi.org/ 10.3390/ijms222111983

Academic Editor: Yin Wang

Received: 7 October 2021

Accepted: 1 November 2021

Published: 5 November 2021

Publisher's Note: MDPI stays neutral with regard to jurisdictional claims in published maps and institutional affiliations.

Copyright: (c) 2021 by the authors. Licensee MDPI, Basel, Switzerland. This article is an open access article distributed under the terms and conditions of the Creative Commons Attribution (CC BY) license (https:// creativecommons.org/licenses/by/ $4.0 /)$.

\begin{abstract}
To study the distance-dependent electromagnetic field effects related to the enhancement and quenching mechanism of surface-enhanced Raman scattering (SERS) or fluorescence, it is essential to precisely control the distance from the surface of the metal nanoparticle (NP) to the target molecule by using a dielectric layer (e.g., $\mathrm{SiO}_{2}, \mathrm{TiO}_{2}$, and $\mathrm{Al}_{2} \mathrm{O}_{3}$ ). However, precisely controlling the thickness of this dielectric layer is challenging. Herein, we present a facile approach to control the thickness of the silica shell on silver nanoparticle-assembled silica nanocomposites, $\mathrm{SiO}_{2} @ \mathrm{Ag} \mathrm{NPs}$, by controlling the number of reacting $\mathrm{SiO}_{2} @ \mathrm{Ag}$ NPs and the silica precursor. Uniform silica shells with thicknesses in the range 5-40 $\mathrm{nm}$ were successfully fabricated. The proposed method for creating a homogeneous, precise, and fine silica coating on nanocomposites can potentially contribute to a comprehensive understanding of the distance-dependent electromagnetic field effects and optical properties of metal NPs.
\end{abstract}

Keywords: silica shell; fine control; shell thickness; assembled structures

\section{Introduction}

Core-shell nanomaterials comprising an inner core and an outer shell have attracted considerable attention due to their properties derived from both the core and the shell materials [1-5]. It has been reported that the surface reactivity [6-9], thermal stability [10,11], colloidal stability $[12,13]$, dispersibility [14,15], absorption [16-18], chemical configuration transition $[19,20]$, and releasing properties $[21,22]$ of core-shell nanomaterials mostly depend on the chemical and physical properties of the shell material. Various encapsulation methods have been extensively studied to prepare core-shell hybrid nanomaterials with excellent functionalities [2].

Shell materials, such as metals [23-25], silica [26-28], polymers [29,30], and glucose [31,32], are often chosen to extend the applications of nanoparticles (NPs). Among these shell materials, silica has been used as an ideal material for preparing core-shell nanomaterials, for example, silica based-metals, -ceramics,-semiconductors, and -magnetics [33], due to its low cost and its excellent properties, such as easy surface modification, optical transparency, chemical inertness, biocompatibility, and easy bio-binding with functional groups $[33,34]$.

The thickness of the silica coating on NPs considerably impacts the physico-chemical properties of core-shell NPs. Phenomena such as metal-enhanced fluorescence (MEF) and surface-enhanced Raman scattering (SERS), which occur on the surfaces of metal NPs due to the intense plasmon-induced electric field, depend strongly on the distance between the metallic surfaces and the coating molecules. Therefore, accurate and fine control of the silica coating of the nanocore particles is necessary. The shell thickness of magnetic NPs affects the distance dependent magnetic field properties of the NPs. However, previous 
studies on the control of silica shell thickness were mainly conducted on single metal NPs, and there are few studies on the extensive fine control and uniformity of the shell [35-38]. In addition, complicated composite NPs as a core-multi-shell NPs with multiplex functions have been studied recently. The disorder of chemical configuration during synthesis leads to a variety of core-multi-shell nanomaterials [20]. Therefore, it is also necessary to study a method for the fine-thickness-control of the coating of composite NPs rather than single metal NPs.

Our research group has developed several silver NP-assembled silica $\left(\mathrm{SiO}_{2} @ \mathrm{Ag}\right) \mathrm{NPs}$ that exhibit multiple properties, such as fluorescence, magnetism, and SERS $[39,40]$. The asprepared NPs showed strong and reproducible Raman enhancement and/or fluorescence at a single NP level [41-44]. In this study, we present a new approach to obtain a fine silica shell coating on composite $\mathrm{SiO}_{2} @ \mathrm{Ag} \mathrm{NPs}\left(\mathrm{SiO}_{2} @ \mathrm{Ag} @ \mathrm{SiO}_{2}\right)$. The silica shell thickness was finely controlled in the range $5-40 \mathrm{~nm}$ by adjusting two parameters: the number of NPs and the amount of silica precursor (sodium silicate $\left(\mathrm{Na}_{2} \mathrm{SiO}_{3}\right)$ and tetraethylorthosilicate (TEOS)) during the silica coating process. This simple method resulted in the formation of a uniform silica shell on the surface of the $\mathrm{SiO}_{2} @ \mathrm{Ag}$ NPs. This technique is expected to be useful in the optimization of the fluorescence and the SERS signal of $\mathrm{SiO}_{2} @ \mathrm{Ag} \mathrm{NPs}$ and opens up an opportunity for the fine control of the silica shell thickness of other nanocomposites.

\section{Results and Discussion}

$\mathrm{SiO}_{2} @ \mathrm{Ag} \mathrm{NPs}$ were prepared as a nanocomposite prior to the silica shell coating. $\mathrm{SiO}_{2}$ NPs, a template for the deposition of Ag NPs, were synthesized by the Stöber method [45]. The surface of the $\mathrm{SiO}_{2} \mathrm{NPs}$ was modified with thiol groups by incubating the NPs with 3-mercaptopropyl trimethoxysilane (MPTS), and then Ag NPs were introduced on the $\mathrm{SiO}_{2}$ surface by the in situ reduction of $\mathrm{Ag}^{+}$ions with a reducing agent (octylamine). The TEM images of the $\mathrm{SiO}_{2}$ NPs and the resultant $\mathrm{SiO}_{2} @ \mathrm{Ag}$ NPs are shown in Figure 1. The $\mathrm{SiO}_{2}$ and $\mathrm{SiO}_{2} @ \mathrm{Ag} \mathrm{NPs}$ were found to be homogeneous and well dispersed without aggregation. The average diameter of the $\mathrm{SiO}_{2} \mathrm{NPs}$ is $153 \pm 2.4 \mathrm{~nm}$ as shown in Figure 1a. After the assembling of the Ag NPs, the average diameter of $\mathrm{SiO}_{2} @ \mathrm{Ag}$ NPs increased up to $192 \pm 7.5 \mathrm{~nm}$, and the Ag NPs with an average size of $21.5 \pm 6.1 \mathrm{~nm}$ were densely assembled on the $\mathrm{SiO}_{2}$ surface (Figure 1b). As shown in Figure S1, the absorption intensity and the extinction maxima of the plasmonic resonance bands significantly changed after the assembly of the Ag NPs on the $\mathrm{SiO}_{2}$ NPs surface. Broad absorption in the range from 322 to $800 \mathrm{~nm}$ with a maximum peak at $430 \mathrm{~nm}$ was exhibited by the $\mathrm{SiO}_{2} @ \mathrm{Ag}$ NPs suspension, indicating that Ag NPs aggregated on the surface of $\mathrm{SiO}_{2}$ NPs [24], which is consistent with the results shown in Figure 1.
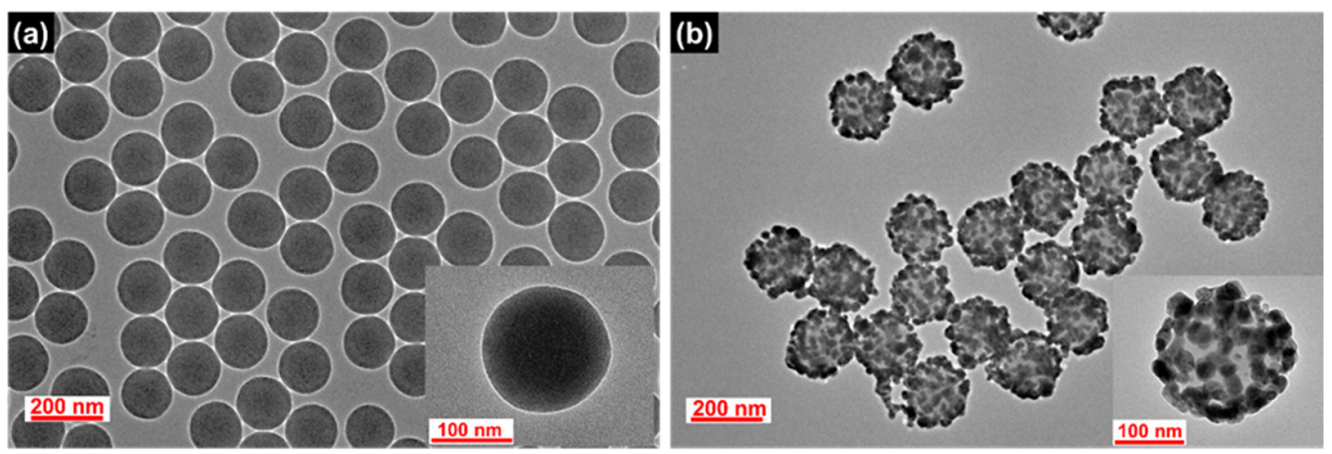

Figure 1. TEM images of the synthesized (a) $\mathrm{SiO}_{2} \mathrm{NPs}$ and (b) $\mathrm{SiO}_{2} @ \mathrm{Ag} \mathrm{NPs}$.

The thickness of the $\mathrm{SiO}_{2}$ shell is highly sensitive to the experimental conditions, which may generate inaccurate and unstable results. It is difficult to evenly form a silica shell with sub-nanometer thickness on the NPs because excessive shell-forming reactions should be excluded to prevent the formation of non-core silica structures such as silica NPs. In our 
procedure, $\mathrm{Na}_{2} \mathrm{SiO}_{3}$ as a silica precursor was added to the aqueous $\mathrm{SiO}_{2} @ \mathrm{Ag} \mathrm{NPs}$ solution, and then the aqueous dispersion was transferred into ethanol. The solvent exchange procedure serves to precipitate the silicate portion (monomer or oligomer) remaining in the solution due to a sharp decrease in solubility, forming a silica shell $[46,47]$. One would expect that a thicker silica shell would form as the amount of $\mathrm{Na}_{2} \mathrm{SiO}_{3}$ is increased. However, experimental results showed that the thick silica shell formation was difficult, and new non-core $\mathrm{SiO}_{2} \mathrm{NPs}$ were generated (Figure S2). On the other hand, it was found that the number of $\mathrm{SiO}_{2} @ \mathrm{Ag} \mathrm{NPs}$ is a key parameter in controlling the thickness of the silica shell (Figure 2). The amount of $\mathrm{SiO}_{2} @ \mathrm{Ag}$ NPs added was adjusted by changing the quantity of $\mathrm{SiO}_{2}(5,10$, and $20 \mathrm{mg})$, while the amount of $\mathrm{Na}_{2} \mathrm{SiO}_{3}$ was fixed at $90 \mu \mathrm{mol}$. The average number of $\mathrm{SiO}_{2} \mathrm{NPs}$ per mg was calculated to be $2.01 \times 10^{11} \pm 9.35 \times 10^{9}$. Therefore, the average number of 5, 10, and $20 \mathrm{mg} \mathrm{SiO} 2$ are $1.01 \times 10^{12} ; 2.01 \times 10^{12}$, and $4.02 \times 10^{12}$, respectively (Table S1). The resultant silica shell thickness of each sample was $5.8 \pm 0.9 \mathrm{~nm}$ (S1), $9.7 \pm 1.2 \mathrm{~nm}$ (S2), and $16.5 \mathrm{~nm} \pm 1.3$ (S3), which correspond to $4.02 \times 10^{12}$ $\mathrm{SiO}_{2} \mathrm{NPs}, 2.01 \times 10^{12} \mathrm{SiO}_{2} \mathrm{NPs}$, and $1.01 \times 10^{12} \mathrm{SiO}_{2} \mathrm{NPs}$, respectively (Figure 2a-c). When the number of $\mathrm{SiO}_{2} @ \mathrm{Ag} \mathrm{NPs}$ is doubled (from $1.01 \times 10^{12} \mathrm{NPs}$ (S3) to $2.01 \times 10^{12}$ NPs (S2), and from $2.01 \times 10^{12} \mathrm{NPs}$ (S2) to $4.02 \times 10^{12} \mathrm{NPs}$ (S1)), the thickness of the silica shell decreased by 6.8 and $3.9 \mathrm{~nm}$, respectively. Therefore, the thickness of the silica layer in S1 to S3 was observed to increase as the number of nanoparticles decreased. The shell thickness is inversely proportional to the cubic root of the number of nanoparticles as shown in the following equation:

$$
\mathrm{SiO}_{2} \text { shell thickness }=\frac{\left[2 \times \sqrt[3]{\left\{\left(\frac{\mathrm{n} \times \mathrm{M}}{\rho \times \mathrm{N}}+V\right) \times \frac{3}{4 \pi}\right\}}-\mathrm{d}\right]}{2}
$$

where $\mathrm{n}$ is the number of mols of $\mathrm{Na}_{2} \mathrm{SiO}_{3}$ or TEOS, $\mathrm{M}$ is the molecular weight of $\mathrm{SiO}_{2}$, $\rho$ is the density of $\mathrm{SiO}_{2}, \mathrm{~N}$ is number of NPs, V is the volume of $\mathrm{SiO}_{2} @ \mathrm{Ag}$, and d is the diameter of $\mathrm{SiO}_{2} @ \mathrm{Ag}$. Indeed, the thicknesses of the silica shells of the nanoparticles (S1 to S3) were found to be consistent with the calculated silica shell values in Table S2, even though the observed values were thicker than the calculated values $(\sim 1.5-1.6 \mathrm{~nm})$.

Although the thickness control of the silica shell was successful as described above, reducing the number of $\mathrm{SiO}_{2} @ \mathrm{Ag} \mathrm{NPs}$ leads to a low yield of the $\mathrm{SiO}_{2} @ \mathrm{Ag} @ \mathrm{SiO}_{2}$ product. To generate a thick silica shell coating on the surface of $\mathrm{SiO}_{2} @ \mathrm{Ag}$ NPs with a desired and reasonable product yield, a secondary silica shell precursor was added into the suspension of $\mathrm{SiO}_{2} @ \mathrm{Ag} \mathrm{NPs}$ coated with silica and $\mathrm{Na}_{2} \mathrm{SiO}_{3}$. Tetraethyl orthosilicate (TEOS) was used as a secondary silica shell precursor in the presence of $\mathrm{NH}_{4} \mathrm{OH}$ (as base catalyst in hydrolysis of TEOS). Homogeneous silica shells with variable thickness were grown on $\mathrm{SiO}_{2} @ \mathrm{Ag}$ NPs by the addition of different volumes of TEOS. TEOS was added into the $\mathrm{S} 2$ suspension $\left(\mathrm{SiO}_{2} @ \mathrm{Ag} \mathrm{NPs}\right.$ coated by $\left.\mathrm{Na}_{2} \mathrm{SiO}_{3}\right)$. TEOS volumes of $88.7,177$, and $266 \mu \mathrm{mol}$ were added into the suspension, which corresponded to the final TEOS concentration of 1.16, 2.33, and $3.49 \mathrm{mM}$, respectively. Figure $2 \mathrm{~d}-\mathrm{f}$ shows the TEM images of the $\mathrm{SiO}_{2} @ \mathrm{Ag} @ \mathrm{SiO}_{2}$ NPs generated by controlling the molar concentration of TEOS in the suspension. The silica shell thicknesses of the $\mathrm{SiO}_{2} @ \mathrm{Ag} @ \mathrm{SiO}_{2} \mathrm{NPs}$ were obtained to be $23.5 \pm 1.8 \mathrm{~nm}$ (S4), $32.6 \pm 1.3 \mathrm{~nm}$ (S5), and $40.1 \pm 2.1 \mathrm{~nm}$ (S6). The thickness of the silica shell increased by approximately 7-9 $\mathrm{nm}$ as the final concentration of TEOS increased from 1.16 to $3.49 \mathrm{mM}$. The observed silica thicknesses of S4-S6 were thicker than those of the calculated values (Table S2). In particular, the ratio of the observed and calculated values of the silica shell thickness was consistent and was higher when TEOS was added to the suspension. Based on these results, we concluded that the number of $\mathrm{SiO}_{2} @ \mathrm{Ag}$ NPs is effective for controlling thin silica coatings and the addition of TEOS is effective for controlling thick silica coatings of $\mathrm{SiO}_{2} @ \mathrm{Ag} \mathrm{NPs}$. The absorbance spectra of $\mathrm{SiO}_{2} @ \mathrm{Ag} @ \mathrm{SiO}_{2} \mathrm{NPs}$ are shown in Figure S3. The spectra of thin silica coated $\mathrm{SiO}_{2} @ \mathrm{Ag}$ NPs were insignificantly different from that of the $\mathrm{SiO}_{2} @ \mathrm{Ag} \mathrm{NPs}$, indicating that no leakage of Ag NPs occurred from the surface of the $\mathrm{SiO}_{2} @ \mathrm{Ag} \mathrm{NPs}$ during the silica shell coating. As expected, a thin silica shell coating does 
not seriously affect the plasmonic resonance properties of thin shell silica coated $\mathrm{SiO}_{2} @ \mathrm{Ag}$ NPs [38]. To demonstrate the stability during storage, $\mathrm{SiO}_{2} @ \mathrm{Ag} @ \mathrm{SiO}_{2} \mathrm{NPs}$ were stored in $\mathrm{EtOH}$ and water for 10 days. The shapes of both $\mathrm{SiO}_{2} @ \mathrm{Ag} @ \mathrm{SiO}_{2} \mathrm{NPs}_{2}$ synthesized using $\mathrm{Na}_{2} \mathrm{SiO}_{3}$ with or without TEOS did not show any significant differences after 10 days in water and EtOH (Figure S4). This study indicates that the $\mathrm{SiO}_{2} @ \mathrm{Ag} @ \mathrm{SiO}_{2} \mathrm{NPs}$ using $\mathrm{Na}_{2} \mathrm{SiO}_{3}$ with or without TEOS are stable when stored in water and EtOH.

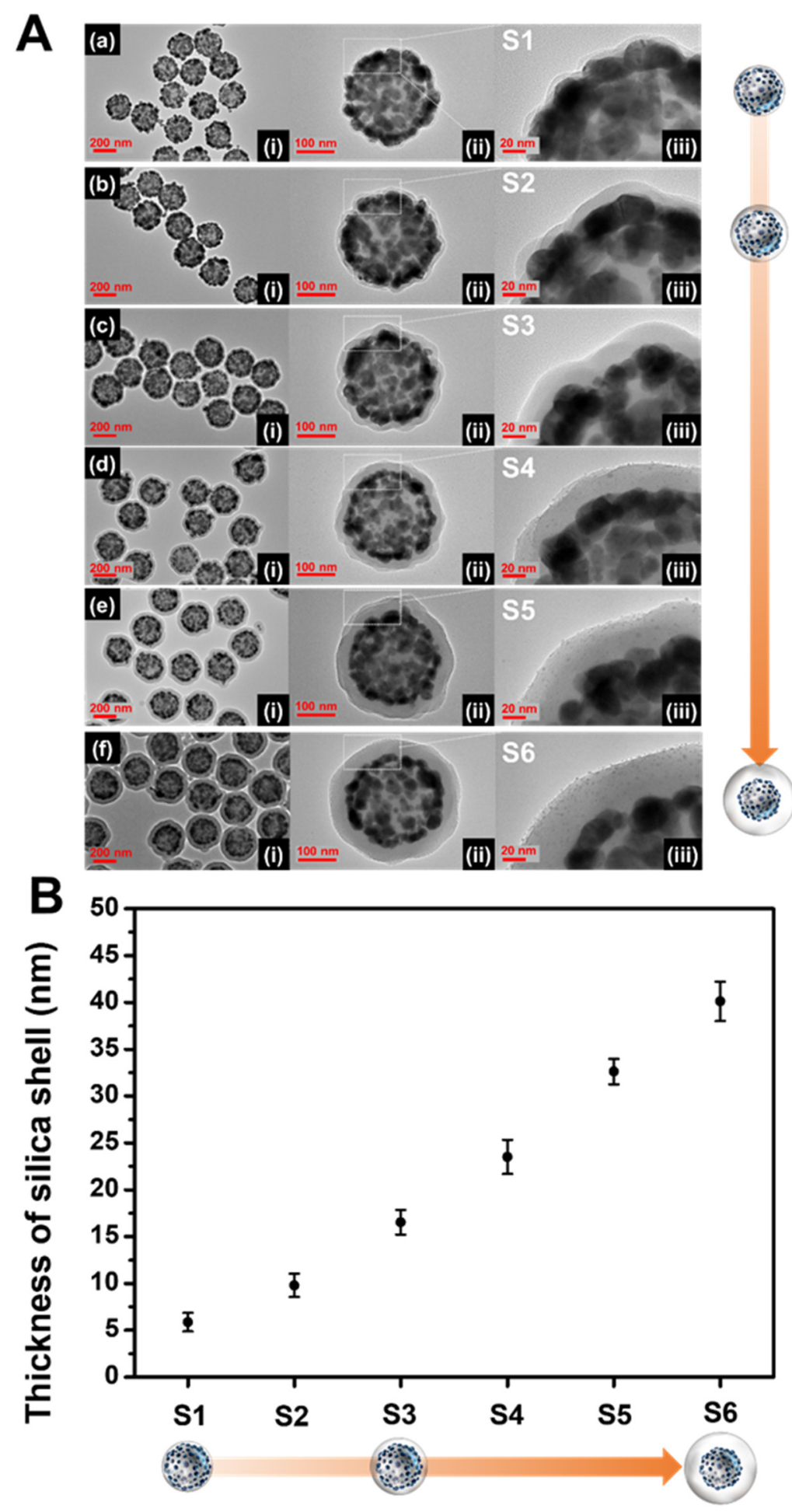

Figure 2. (A) TEM images at (i) low and (ii, iii) high magnifications. (B) The thickness of the silica shell layer on the surface of the $\mathrm{SiO}_{2} @ \mathrm{Ag}$ NPs synthesized under various conditions (a-f). 


\section{Materials and Methods}

\subsection{Materials}

Tetraethylorthosilicate (TEOS), ethyl alcohol (EtOH, 99.5\% and 95\%), 3-mercaptopropyl trimethoxysilane (MPTS), silver nitrate $\left(\mathrm{AgNO}_{3}\right)$, polyvinylpyrrolidone (PVP, MW 40,000), ethylene glycol $(\mathrm{EG})$, octylamine $(\mathrm{OA})$, hydrochloric acid $(\mathrm{HCl})$, sodium hydroxide $(\mathrm{NaOH})$, and acetone were purchased from Sigma-Aldrich (St. Louis, MO, USA) and used without further purification. Aqueous ammonium hydroxide $\left(\mathrm{NH}_{4} \mathrm{OH}, 27 \%\right)$ was purchased from Daejung (Siheung, Gyeonggi-do, Korea). Water was purified using a Direct-Q Millipore water purification system (SAM WOO S\&T Co., Ltd., Seoul, Korea).

\subsection{Methods}

\subsubsection{Synthesis of Ag-Embedded Silica Nanoparticles ( $\left.\mathrm{SiO}_{2} @ \mathrm{Ag} \mathrm{NPs}\right)$}

$\mathrm{SiO}_{2}$ NPs ( 153 nm) were synthesized using the modified Stöber method. TEOS $(1.6 \mathrm{~mL})$ was added to $\mathrm{EtOH}(40 \mathrm{~mL})$ in a round flask. Then, $\mathrm{NH}_{4} \mathrm{OH}(3 \mathrm{~mL})$ was added quickly to this solution. The mixture was vigorously stirred at $700 \mathrm{rpm}$ for $20 \mathrm{~h}$ at room temperature (RT). Then, the mixture was centrifuged $(8500 \mathrm{rpm}, 15 \mathrm{~min})$ and washed 3 times with EtOH to remove the excess reagents. After washing, the $\mathrm{SiO}_{2} \mathrm{NPs}_{\text {sere }}$ dispersed in $\mathrm{EtOH}$, and the $\mathrm{SiO}_{2}$ concentration was adjusted to $50 \mathrm{mg} \cdot \mathrm{mL}^{-1}$.

To embed Ag NPs on the $\mathrm{SiO}_{2}$ surface, the $\mathrm{SiO}_{2} \mathrm{NP}$ suspension was incubated with MPTS to transfer the hydroxyl groups on its surface to the thiol groups. In particular, the $\mathrm{SiO}_{2}$ NPs $\left(50 \mathrm{mg} \cdot \mathrm{mL}^{-1}, 4 \mathrm{~mL}\right)$ were added to EtOH $(4 \mathrm{~mL})$. Then, MPTS $(200 \mu \mathrm{L})$ and $\mathrm{NH}_{4} \mathrm{OH}(40 \mu \mathrm{L})$ were added to the solution. The suspension was vigorously stirred at $700 \mathrm{rpm}$ for $12 \mathrm{~h}$ at RT. After the reaction, the suspension was centrifuged and washed 3 times with $\mathrm{EtOH}$. The final concentration of thiolated $\mathrm{SiO}_{2}\left(\mathrm{SiO}_{2}-\mathrm{SH}\right)$ was adjusted to $50 \mathrm{mg} \cdot \mathrm{mL}^{-1}$.

Ag NPs were attached on the $\mathrm{SiO}_{2}-\mathrm{SH}$ by reducing $\mathrm{AgNO}_{3}$ with octylamine in EG. PVP (5 mg) was dissolved in EG (25 mL). AgNO 3 (26 mg) dissolved in EG (25 mL) was suspended in this PVP solution. $\mathrm{SiO}_{2}-\mathrm{SH}(30 \mathrm{mg})$ was then added to this suspension Octylamine $(41.4 \mu \mathrm{L})$ was sequentially added and the suspension was vigorously stirred at $700 \mathrm{rpm}$ for $1 \mathrm{~h}$ at RT. Then, the suspension was centrifuged and washed 5 times with $\mathrm{EtOH}$.

\subsubsection{Synthesis of $\mathrm{SiO}_{2} @ \mathrm{Ag}$ NPs with Silica Shells of Different Thicknesses}

- $\quad$ Effect of the amount of the $\mathrm{SiO}_{2} @ \mathrm{Ag}$ NPs on the silica shell thickness

Various amounts of the $\mathrm{SiO}_{2} @ \mathrm{Ag}$ NPs $(5,10$, and $20 \mathrm{mg})$ were dispersed in $\mathrm{EtOH}$ $(1 \mathrm{~mL})$. The $\mathrm{SiO}_{2} @ \mathrm{Ag}$ NPs suspension was added in distilled water $(15 \mathrm{~mL})$ containing $\mathrm{Na}_{2} \mathrm{SiO}_{3}$ solution $(14.4 \mu \mathrm{L})$. The suspension was stirred at $700 \mathrm{rpm}$ for $1 \mathrm{~h}$, and $\mathrm{EtOH}$ $(60 \mathrm{~mL})$ was added in the suspension, followed by stirring for $3 \mathrm{~h}$. After stirring, the suspension was centrifuged at $8500 \mathrm{rpm}$ for $15 \mathrm{~min}$ and washed by EtOH 3 times.

- $\quad$ Effect of the TEOS volume on silica shell thickness

$\mathrm{SiO}_{2} @ \mathrm{Ag} \mathrm{NPs}(10 \mathrm{mg})$ were dispersed in $1 \mathrm{~mL}$ of $\mathrm{EtOH}$. The $\mathrm{SiO}_{2} @ \mathrm{Ag} \mathrm{NPs}$ suspension was added in distilled water $(15 \mathrm{~mL})$ containing $\mathrm{Na}_{2} \mathrm{SiO}_{3}$ solution $(14.4 \mu \mathrm{L})$. The suspension was stirred at $700 \mathrm{rpm}$ for $1 \mathrm{~h}$, and $\mathrm{EtOH}(60 \mathrm{~mL})$ was added in the suspension, followed by stirring for $3 \mathrm{~h}$. Then, various volumes of TEOS $(20,40$, and $60 \mu \mathrm{L})$ were added to the suspension under stirring. $\mathrm{NH}_{4} \mathrm{OH}(250 \mu \mathrm{L})$ was also added to the suspension, and the suspension was continuously stirred for $24 \mathrm{~h}$. After stirring, the suspension was centrifuged at $8500 \mathrm{rpm}$ for $15 \mathrm{~min}$ and washed 3 times with EtOH to remove excess reagents.

\subsubsection{Measurement of UV-Vis Absorption Spectra}

The particles were dispersed in EtOH $\left(2 \mathrm{mg} \cdot \mathrm{mL}^{-1}\right)$ and transferred to a cuvette. UVVis absorption of the sample was performed using a UV-Vis spectrophotometer (Mecasys OPTIZEN POP, Daejeon, Korea). 


\subsubsection{Transmission Electron Microscopy (TEM) Imaging}

The particles were dispersed in $\mathrm{EtOH}\left(2 \mathrm{mg} \cdot \mathrm{mL}^{-1}\right)$. Then, $10 \mu \mathrm{L}$ of the sample was dropped on a copper grid (400 Mesh Cu, Pelco, Presno, CA, USA) and dried at RT. The size and morphology of the samples were observed by TEM (Libra 120, Carl Zeiss, Oberkochen, Germany).

\subsubsection{Measurement of the Size of the $\mathrm{SiO}_{2} \mathrm{NPs}$}

The size of the nanoparticles and the thickness of the $\mathrm{SiO}_{2}$ shell were analyzed by digitalized measurement using Image J software (Bethesda, MD, USA). The average size of the NPs and the thickness of the $\mathrm{SiO}_{2}$ shell were calculated after analyzing at least 60 NPs.

\section{Conclusions}

In summary, the silica shell thickness of $\mathrm{SiO}_{2} @ \mathrm{Ag} \mathrm{NPs}$ was finely tuned in the range 5-40 $\mathrm{nm}$ by adjusting the number of $\mathrm{SiO}_{2} @ \mathrm{Ag}$ NPs and the TEOS concentration. The silica shell thickness of $\mathrm{SiO}_{2} @ \mathrm{Ag}$ NPs was found to be inversely proportional to the number of $\mathrm{SiO}_{2} @ \mathrm{Ag} \mathrm{NPs}$ and proportional to the volume of TEOS. Thin silica shells with thickness in the range 5.8-16.5 nm were formed on the surface of $\mathrm{SiO}_{2} @ \mathrm{Ag} \mathrm{NP}$ when the number of $\mathrm{SiO}_{2} @ \mathrm{Ag} \mathrm{NPs}$ decreased from $4.02 \times 10^{12} \mathrm{NPs}$ to $1.01 \times 10^{12} \mathrm{NPs}$. In addition, the silica shell thickness increased from 23.5 to $40.1 \mathrm{~nm}$ when the final TEOS concentration was increased from 1.16 to $3.49 \mathrm{mM}$. In general, we obtained $\mathrm{SiO}_{2} @ \mathrm{Ag} @ \mathrm{SiO}_{2} \mathrm{NPs}$ with silica shell thicknesses of $5.8 \pm 0.9,9.7 \pm 1.2,16.5 \pm 1.3,23.5 \pm 1.8,32.6 \pm 1.3$, and $40.1 \pm 2.1 \mathrm{~nm}$ by adjusting the number of $\mathrm{SiO}_{2} @ \mathrm{Ag}$ NPs and the silica precursor volume. As expected, a thin silica shell coating on the surface of $\mathrm{SiO}_{2} @ \mathrm{Ag}$ NPs does not seriously affect the plasmonic resonance properties of $\mathrm{SiO}_{2} @ \mathrm{Ag}$ NPs. The successful coating of the thin and homogenous silica shell on the surface of $\mathrm{SiO}_{2} @ \mathrm{Ag} \mathrm{NP}$ was found to provide colloidal stability to the nanocomposite. The proposed technique is expected to be useful for understanding the distance-dependent electromagnetic field effects of SERS enhancement, MEF effect, and the quenching of complex NPs in sol-phase.

Supplementary Materials: The following are available online at https:/ / www.mdpi.com/article/10 .3390/ijms222111983/s1.

Author Contributions: E.H. and B.-H.J. conceived and designed the experiments. E.H., A.J. and E.J.K. performed the experiments. E.H., A.J., E.J.K., S.B. and X.-H.P. analyzed the data. E.H., A.J., E.J.K. and X.-H.P. wrote the manuscript. B.-H.J. and H.C. edited manuscript. B.-H.J. and H.C. supervised the overall work. All authors have read and agreed to the published version of the manuscript.

Funding: This research was funded by the National Research Foundation (NRF) of Korea (NRF2017H1A2A1044051-Fostering Core Leaders of the Future Basic Science Program/Global Ph.D. Fellowship Program) and by the Korean Government (MSIT) (No.2019R1G1A1100734). This study was also supported by Konkuk University (2018A0190462).

Institutional Review Board Statement: Not applicable.

Informed Consent Statement: Not applicable.

Data Availability Statement: Data is contained within the article and supplementary material.

Acknowledgments: The authors are grateful for the financial support from the NRF of Korea, Korean Government (MIST) and from the Konkuk University.

Conflicts of Interest: The authors declare no conflict of interest.

\section{References}

1. Kalambate, P.K.; Huang, Z.; Li, Y.; Shen, Y.; Xie, M.; Huang, Y.; Srivastava, A.K. Core@ shell nanomaterials based sensing devices: A review. TrAC Trends Anal. Chem. 2019, 115, 147-161. [CrossRef]

2. Ghosh Chaudhuri, R.; Paria, S. Core/shell nanoparticles: Classes, properties, synthesis mechanisms, characterization, and applications. Chem. Rev. 2012, 112, 2373-2433. [CrossRef] 
3. Li, J.-F.; Zhang, Y.-J.; Ding, S.-Y.; Panneerselvam, R.; Tian, Z.-Q. Core-shell nanoparticle-enhanced Raman spectroscopy. Chem. Rev. 2017, 117, 5002-5069. [CrossRef]

4. Mahdavi, Z.; Rezvani, H.; Moraveji, M.K. Core-shell nanoparticles used in drug delivery-microfluidics: A review. RSC Adv. 2020, 10, 18280-18295. [CrossRef]

5. Schärtl, W. Current directions in core-shell nanoparticle design. Nanoscale 2010, 2, 829-843. [CrossRef] [PubMed]

6. Xie, J.; Zhang, Q.; Gu, L.; Xu, S.; Wang, P.; Liu, J.; Ding, Y.; Yao, Y.F.; Nan, C.; Zhao, M. Ruthenium-platinum core-shell nanocatalysts with substantially enhanced activity and durability towards methanol oxidation. Nano Energy 2016, 21, 247-257. [CrossRef]

7. Chen, T.Y.; Lin, T.L.; Luo, T.J.M.; Choi, Y.; Lee, J.F. Effects of Pt shell thicknesses on the atomic structure of Ru-Pt core-shell nanoparticles for methanol electrooxidation applications. ChemPhysChem 2010, 11, 2383-2392. [CrossRef] [PubMed]

8. Hui, Y.; Yang, G.; Fu, C.; Liu, Y.; Zhao, C.-X. Biomimetic core-shell silica nanoparticles using a dual-functional peptide. J. Colloid Interface Sci. 2021, 581, 185-194.

9. Yang, F.; Chu, Y.; Ma, S.; Zhang, Y.; Liu, J. Preparation of uniform silica/polypyrrole core/shell microspheres and polypyrrole hollow microspheres by the template of modified silica particles using different modified agents. J. Colloid Interface Sci. 2006, 301, 470-478. [CrossRef]

10. Tsai, C.-H.; Chen, S.-Y.; Song, J.-M.; Chen, I.-G.; Lee, H.-Y. Thermal stability of Cu@Ag core-shell nanoparticles. Corros. Sci. 2013, 74, 123-129. [CrossRef]

11. Wen, Y.-H.; Huang, R.; Shao, G.-F.; Sun, S.-G. Thermal stability of Co-Pt and Co-Au core-shell structured nanoparticles: Insights from molecular dynamics simulations. J. Phys. Chem. Lett. 2017, 8, 4273-4278. [CrossRef] [PubMed]

12. Zhou, Z.; Gu, J.; Qiao, X.; Wu, H.; Fu, H.; Wang, L.; Li, H.; Ma, L. Double protected lanthanide fluorescence core@ shell colloidal hybrid for the selective and sensitive detection of $\mathrm{ClO}^{-}$. Sens. Actuators B Chem. 2019, 282, 437-442. [CrossRef]

13. Szekeres, M.; Tóth, I.Y.; Illés, E.; Hajdú, A.; Zupkó, I.; Farkas, K.; Oszlánczi, G.; Tiszlavicz, L.; Tombácz, E. Chemical and colloidal stability of carboxylated core-shell magnetite nanoparticles designed for biomedical applications. Int. J. Mol. Sci. 2013, 14, 14550-14574. [CrossRef] [PubMed]

14. Li, W.; Zhao, D. Extension of the Stöber Method to Construct Mesoporous $\mathrm{SiO}_{2}$ and $\mathrm{TiO}_{2}$ Shells for Uniform Multifunctional Core-Shell Structures; Wiley Online Library: Hoboken, NJ, USA, 2013.

15. Chen, S.; Bedia, J.; Li, H.; Ren, L.Y.; Naluswata, F.; Belver, C. Nanoscale zero-valent iron@ mesoporous hydrated silica core-shell particles with enhanced dispersibility, transportability and degradation of chlorinated aliphatic hydrocarbons. Chem. Eng. J. 2018, 343, 619-628. [CrossRef]

16. Isa, L.; Amstad, E.; Schwenke, K.; Del Gado, E.; Ilg, P.; Kröger, M.; Reimhult, E. Adsorption of core-shell nanoparticles at liquid-liquid interfaces. Soft Matter 2011, 7, 7663-7675. [CrossRef]

17. Wu, J.; Zhu, H.; Liu, G.; Tan, L.; Hu, X.; Chen, C.; Alharbi, N.S.; Hayat, T.; Tan, X. Fabrication of core-shell CMNP@ PmPD nanocomposite for efficient As (V) adsorption and reduction. ACS Sustain. Chem. Eng. 2017, 5, 4399-4407. [CrossRef]

18. Li, Y.; Yang, C.-X.; Yan, X.-P. Controllable preparation of core-shell magnetic covalent-organic framework nanospheres for efficient adsorption and removal of bisphenols in aqueous solution. Chem. Commun. 2017, 53, 2511-2514. [CrossRef] [PubMed]

19. Langlois, C.; Li, Z.L.; Yuan, J.; Alloyeau, D.; Nelayah, J.; Bochicchio, D.; Ferrando, R.; Ricolleau, C. Transition from core-shell to Janus chemical configuration for bimetallic nanoparticles. Nanoscale 2012, 4, 3381-3388. [CrossRef]

20. Nelli, D.; Ferrando, R. Core-shell vs. multi-shell formation in nanoalloy evolution from disordered configurations. Nanoscale 2019, 11, 13040-13050. [CrossRef]

21. Narayanan, S.; Pavithran, M.; Viswanath, A.; Narayanan, D.; Mohan, C.C.; Manzoor, K.; Menon, D. Sequentially releasing dual-drug-loaded PLGA-casein core/shell nanomedicine: Design, synthesis, biocompatibility and pharmacokinetics. Acta Biomater. 2014, 10, 2112-2124. [CrossRef]

22. Soppimath, K.S.; Tan, D.W.; Yang, Y.Y. pH-triggered thermally responsive polymer core-shell nanoparticles for drug delivery. Adv. Mater. 2005, 17, 318-323. [CrossRef]

23. Cha, M.G.; Kang, H.; Choi, Y.-S.; Cho, Y.; Lee, M.; Lee, H.-Y.; Lee, Y.-S.; Jeong, D.H. Effect of alkylamines on morphology control of silver nanoshells for highly enhanced Raman scattering. ACS Appl. Mater. Interfaces 2019, 11, 8374-8381. [CrossRef] [PubMed]

24. Hahm, E.; Cha, M.G.; Kang, E.J.; Pham, X.-H.; Lee, S.H.; Kim, H.-M.; Kim, D.-E.; Lee, Y.-S.; Jeong, D.-H.; Jun, B.-H. Multilayer Ag-embedded silica nanostructure as a surface-enhanced raman scattering-based chemical sensor with dual-function internal standards. ACS Appl. Mater. Interfaces 2018, 10, 40748-40755. [CrossRef]

25. Pham, X.-H.; Hahm, E.; Kang, E.; Ha, Y.N.; Lee, S.H.; Rho, W.-Y.; Lee, Y.-S.; Jeong, D.H.; Jun, B.-H. Gold-silver bimetallic nanoparticles with a Raman labeling chemical assembled on silica nanoparticles as an internal-standard-containing nanoprobe. J. Alloys Compd. 2019, 779, 360-366. [CrossRef]

26. Pham, X.-H.; Hahm, E.; Kim, H.-M.; Son, B.S.; Jo, A.; An, J.; Tran Thi, T.A.; Nguyen, D.Q.; Jun, B.-H. Silica-coated magnetic iron oxide nanoparticles grafted onto graphene oxide for protein isolation. Nanomaterials 2020, 10, 117. [CrossRef]

27. Poovarodom, S.; Bass, J.D.; Hwang, S.-J.; Katz, A. Investigation of the Core- Shell Interface in Gold@ Silica Nanoparticles: A Silica Imprinting Approach. Langmuir 2005, 21, 12348-12356. [CrossRef]

28. Li, J.F.; Huang, Y.F.; Ding, Y.; Yang, Z.L.; Li, S.B.; Zhou, X.S.; Fan, F.R.; Zhang, W.; Zhou, Z.Y.; Ren, B. Shell-isolated nanoparticleenhanced Raman spectroscopy. Nature 2010, 464, 392-395. [CrossRef] 
29. Dong, H.; Zhu, M.; Yoon, J.A.; Gao, H.; Jin, R.; Matyjaszewski, K. One-pot synthesis of robust core/shell gold nanoparticles. J. Am. Chem. Soc. 2008, 130, 12852-12853. [CrossRef]

30. Xiong, H.-M.; Xu, Y.; Ren, Q.-G.; Xia, Y.-Y. Stable aqueous ZnO@ polymer core-shell nanoparticles with tunable photoluminescence and their application in cell imaging. J. Am. Chem. Soc. 2008, 130, 7522-7523. [CrossRef] [PubMed]

31. Fang, X.; Wang, S.; Li, Y.; Liu, X.; Li, X.; Lin, S.; Cui, Z.-K.; Zhuang, Q. $\mathrm{NH}_{2}$-functionalized carbon-coated Fe ${ }_{3} \mathrm{O}_{4}$ core-shell nanoparticles for in situ preparation of robust polyimide composite films with high dielectric constant, low dielectric loss, and high breakdown strength. RSC Adv. 2016, 6, 107533-107541. [CrossRef]

32. Venturelli, L.; Nappini, S.; Bulfoni, M.; Gianfranceschi, G.; Dal Zilio, S.; Coceano, G.; Del Ben, F.; Turetta, M.; Scoles, G.; Vaccari, L. Glucose is a key driver for GLUT1-mediated nanoparticles internalization in breast cancer cells. Sci. Rep. 2016, 6, 21629. [CrossRef] [PubMed]

33. Guerrero-Martínez, A.; Pérez-Juste, J.; Liz-Marzán, L.M. Recent progress on silica coating of nanoparticles and related nanomaterials. Adv. Mater. 2010, 22, 1182-1195. [CrossRef]

34. Vasudevan, D.; Gaddam, R.R.; Trinchi, A.; Cole, I. Core-shell quantum dots: Properties and applications. J. Alloys Compd. 2015, 636, 395-404. [CrossRef]

35. El-Toni, A.M.; Yin, S.; Sato, T. Control of silica shell thickness and microporosity of titania-silica core-shell type nanoparticles to depress the photocatalytic activity of titania. J. Colloid Interface Sci. 2006, 300, 123-130. [CrossRef]

36. Tian, X.D.; Liu, B.J.; Li, J.F.; Yang, Z.L.; Ren, B.; Tian, Z.Q. SHINERS and plasmonic properties of Au Core $\mathrm{SiO}_{2} \mathrm{shell}_{\text {nanoparticles }}$ with optimal core size and shell thickness. J. Raman Spectrosc. 2013, 44, 994-998. [CrossRef]

37. Narita, A.; Naka, K.; Chujo, Y. Facile control of silica shell layer thickness on hydrophilic iron oxide nanoparticles via reverse micelle method. Colloids Surf. A Physicochem. Eng. Asp. 2009, 336, 46-56. [CrossRef]

38. Vanderkooy, A.; Chen, Y.; Gonzaga, F.; Brook, M.A. Silica shell/gold core nanoparticles: Correlating shell thickness with the plasmonic red shift upon aggregation. ACS Appl. Mater. Interfaces 2011, 3, 3942-3947. [CrossRef] [PubMed]

39. Jun, B.H.; Kim, G.; Jeong, S.; Noh, M.S.; Pham, X.H.; Kang, H.; Cho, M.H.; Kim, J.H.; Lee, Y.S.; Jeong, D.H. Silica Core-based Surface-enhanced Raman Scattering (SERS) Tag: Advances in Multifunctional SERS Nanoprobes for Bioimaging and Targeting of Biomarkers ${ }^{\#}$. Bull. Korean Chem. Soc. 2015, 36, 963-978.

40. Kim, H.-M.; Kim, D.-M.; Jeong, C.; Park, S.Y.; Cha, M.G.; Ha, Y.; Jang, D.; Kyeong, S.; Pham, X.-H.; Hahm, E. Assembly of plasmonic and magnetic nanoparticles with fluorescent silica shell layer for tri-functional SERS-magnetic-fluorescence probes and its bioapplications. Sci. Rep. 2018, 8, 13938. [CrossRef]

41. Jeong, S.; Kim, Y.-i.; Kang, H.; Kim, G.; Cha, M.G.; Chang, H.; Jung, K.O.; Kim, Y.-H.; Jun, B.-H.; Lee, Y.-S. Fluorescence-Raman dual modal endoscopic system for multiplexed molecular diagnostics. Sci. Rep. 2015, 5, 9455. [CrossRef]

42. Jun, B.-H.; Kim, G.; Noh, M.S.; Kang, H.; Kim, Y.-K.; Cho, M.-H.; Jeong, D.H.; Lee, Y.-S. Surface-enhanced Raman scattering-active nanostructures and strategies for bioassays. Nanomedicine 2011, 6, 1463-1480. [CrossRef] [PubMed]

43. Kim, H.-M.; Jeong, S.; Hahm, E.; Kim, J.; Cha, M.G.; Kim, K.-M.; Kang, H.; Kyeong, S.; Pham, X.-H.; Lee, Y.-S. Large scale synthesis of surface-enhanced Raman scattering nanoprobes with high reproducibility and long-term stability. J. Ind. Eng. Chem. 2016, 33, 22-27. [CrossRef]

44. Hahm, E.; Kim, Y.-H.; Pham, X.-H.; Jun, B.-H. Highly reproducible surface-enhanced Raman scattering detection of alternariol using silver-embedded silica nanoparticles. Sensors 2020, 20, 3523. [CrossRef] [PubMed]

45. Stöber, W.; Fink, A.; Bohn, E. Controlled growth of monodisperse silica spheres in the micron size range. J. Colloid Interface Sci. 1968, 26, 62-69. [CrossRef]

46. Buining, P.A.; Liz-Marzán, L.M.; Philipse, A.P. A simple preparation of small, smooth silica spheres in a seed alcosol for Stöber synthesis. J. Colloid Interface Sci. 1996, 179, 318-321. [CrossRef]

47. Correa-Duarte, M.A.; Giersig, M.; Liz-Marzán, L.M. Stabilization of CdS semiconductor nanoparticles against photodegradation by a silica coating procedure. Chem. Phys. Lett. 1998, 286, 497-501. [CrossRef] 